\title{
CRIMINAL AND LEGAL CHARACTERISTICS OF TRANSNATIONAL CRIME: COMPARATIVE ANALYSIS
}

\section{КРИМІНАЛЬНО-ПРАВОВА ХАРАКТЕРИСТИКА ТРАНСНАЦІОНАЛЬНОЇ ЗЛОЧИННОСТІ: ПОРІВНЯЛЬНИЙ АНАЛІЗ}

\section{Oleksandra Skok ${ }^{1}$ \\ Taisiia Shevchenko}

DOI: https://doi.org/10.30525/978-9934-26-077-3-39

\begin{abstract}
This article focuses on the criminal law characteristics of transnational crime, which has an extremely negative impact on the economic and social spheres of modern society in many countries. The provisions of international regulations on the definition of transnational crime and the reality of implementation of international agreements signed and ratified by Ukraine in terms of implementation in national criminal law of liability for crimes with transnational links have been thoroughly studied. In particular, the United Nations Convention against Transnational Organized Crime and the Agreement between Ukraine and the European Police Office on Operational and Strategic Cooperation and other international regulations on cooperation of member states in combating transnational crime were studied. The statistical data of the General Prosecutor's Office of Ukraine are analyzed, which indicate the negative dynamics of the state of organized crime, which has increased over the last five years. The article presents official statistics, according to which in 2016 the share of organized crime amounted to $0.02 \%$ of the total number of crimes committed; in $2017-0.04 \%$; in $2018-0.06 \%$, in $2019-0.07 \%$, in $2020-0.1 \%$ - which indicates an increase in the level of organized crime in general. An analysis of international regulations signed or ratified by Ukraine on the definition of transnational crime is carried out. The dispositions of the norms of the criminal legislation on detection of signs

${ }^{1}$ Candidate of Sciences in Law,

Associate Professor at the Department of Criminal-Legal Disciplines,

Dnipropetrovsk State University of Internal Affairs, Ukraine

${ }^{2}$ Senior Lecturer at the Department of Criminal-Legal Disciplines,

Dnipropetrovsk State University of Internal Affairs, Ukraine
\end{abstract}


of crimes with transnational connections are analyzed. Crimes with signs of transnational crime have been identified under national legislation and the legislation of some foreign countries, on the basis of which their comparative characteristics have been made. It is established that some foreign countries also regulate the possibility of applying exemptions from criminal liability for similar criminal offenses under the domestic law on criminal liability. In particular, the norms of the Criminal Code of the Republic of Kazakhstan, the Republic of Azerbaijan, Georgia, the Republic of Moldova, the Republic of Turkmenistan, the Republic of Tajikistan, the Republic of Kyrgyzstan, the Republic of Armenia are analyzed. The article identifies a list of crimes that may have signs of transnational crime. It has been established that the largest number of crimes that may have the characteristics of transnational crime are acts related to drug trafficking, human trafficking, smuggling, economic crimes, arms trafficking, smuggling and other closely related crimes. with border crossing and international criminal relations. On this basis, it is proposed to set out the disposition of Part 2 of Art. 201 of the Criminal Code of Ukraine, which provides for liability for smuggling, taking into account the new qualifier for the commission of this act by criminal groups with transnational ties. In addition, the problem of the lack of definition of transnational crime at the legislative level in Ukraine, which prompts further research in this area, has been identified.

\section{1. Ветуп}

На шляху України до Євроінтеграції однією із задач стоїть відповідність національного законодавства до міжнародних стандартів. За останні п'ять років було внесено зміни до Особливої частини Кримінального кодексу України (далі - КК), які безпосередньо стосуються кримінальних правопорушень проти статевої свободи та статевої недоторканості особи (ст. ст. 152, 153, 156, $156^{1}$ КК), кримінальних правопорушень проти громадської безпеки (ст. ст. $255,255^{1}, 255^{2}, 255^{3}$, 256 КК), кримінальних правопорушень проти громадського порядку та моральності (ст. ст. $301^{1}, 301^{2}$ КК) та інших. Однак, не має визначення транснаціональної злочинності за національним кримінальним законодавством, незважаючи на те, що однак Україною ратифіковані низка міжнародних нормативно-правових актів та укладені міжнародні договори щодо протидії транснаціональній злочинності. 
За офіційними даними Генеральної прокуратури, за останні п’ять років відбувається негативна динаміка стану організованої злочинності, яка має тенденцію до щорічного збільшення. Якісна характеристика організованої злочинності як структурна частина загальної кількості злочинності складає взагалі невелику частку. Так, у 2016 році питома вага організованої злочинності склала 0,02 \% від загальної кількості вчинених злочинів; у 2017 році питома вага ОГ та 30 склала 0,04\%; у 2018 році питома вага склала вже $0,06 \%$, у в 2019 році - 0,07\%, у 2020 році такий показник склав - 0,1\%. Тож на фоні загального зниження рівня злочинності у 2018-2020 роках рівень організованої злочинності збільшився. Крім того, це стосується як самих груп, так і кількості їх учасників. Крім того варто зазначити, що є негативна динаміка щодо транснаціональної організованої злочинності і відсоток викриття груп з ознаками транснаціональних зв'язків невеликий. За п’ять років в Україні викрито лише одну злочинну організацію 3 ознаками транснаціональних зв'язків. Щодо кількості осіб, які вчинили кримінальні правопорушення в складі організованих груп та злочинних організацій з транснаціональними зв'язками їх кількість зросла 3 30 осіб у 2016 році до 58 у 2020 році [1].

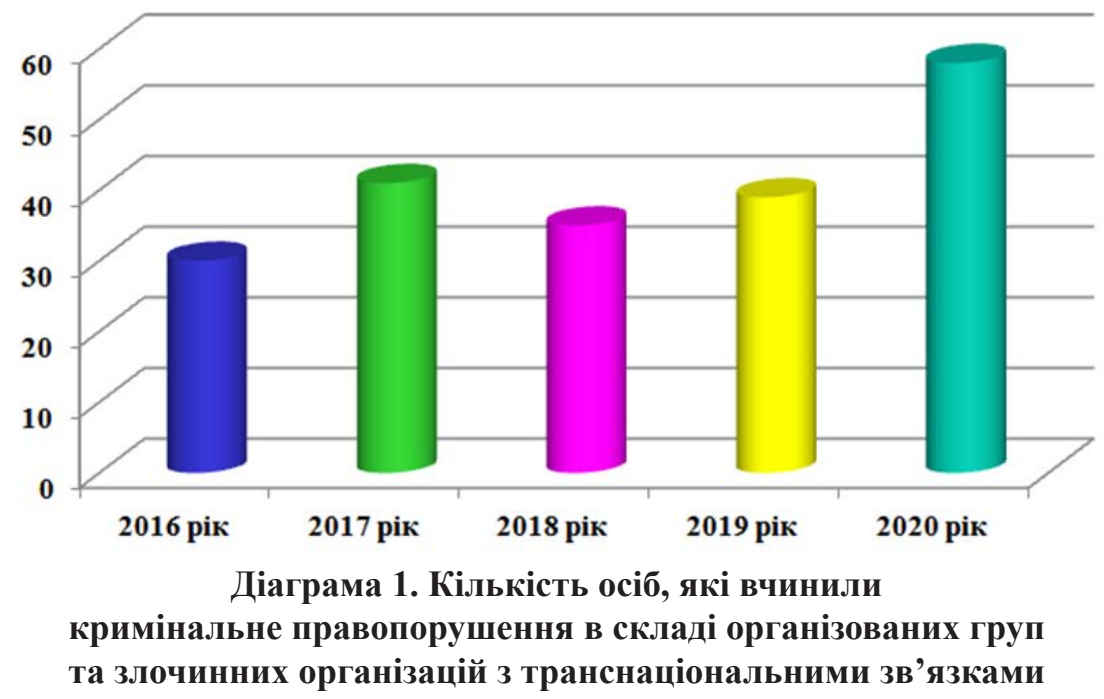


Метою цього дослідження є аналіз міжнародних актів щодо визначення транснаціональної злочинності та виконання міжнародних угод, які підписані та ратифіковані Україною щодо імплементації в національне кримінальне законодавство щодо особливостей відповідальності за вчинення злочинів з ознаками транснаціональної злочинності.

Окремі питання транснаціональної організованої злочинності висвітлювали в своїх працях такі вчені, як: Біленчук П.Д., Борисов В.І., Жаровська Г.П., Калиновський В.Б., Полянська В.С., Сидоров В.І. та інші.

Однак, проведені дослідження стосувались заходів протидії транснаціональної організованої злочинності, питанням міжнародної співпраці у цьому питанню або бралось більш вузький напрямок дослідження пов'язаний з окремим видом злочинності (наркозлочинність, торгівля людьми, економічна сфера). Визначення злочинів з ознаками транснаціональної організованої злочинності кримінально-правового характеру недостатньо розглянута і потребує конкретного визначення.

\section{2. Аналіз міжнародних нормативно-правових актів підписаних або ратифікованих Україною щодо визначення транснаціональної злочинності}

Україна як держава-учасниця ратифікувала Конвенцію проти транснаціональної організованої злочинності 04.02.2004 р. Метою Конвенції згідно ст. $1 €$ сприяння співробітництву в справі більш ефективного попередження транснаціональної організованої злочинності та боротьби з нею. Згідно ст. 3 Конвенції ООН проти транснаціональної організованої злочинності, злочин носить транснаціональний характер, якщо: він вчинений у більш ніж одній державі; він вчинений в одній державі, але істотна частина його підготовки, планування, керівництва або контролю має місце в іншій державі; він вчинений в одній державі, але за участю організованої злочинної групи, яка здійснює злочинну діяльність у більш ніж одній державі; він вчинений в одній державі, але його істотні наслідки мають місце в іншій державі [2].

Поняття транснаціональної злочинності за національним кримінальним законодавством не визначено. Однак, на підставі ст. 5 Конвенції ООН проти транснаціональної організованої злочинності кожна Держава-учасниця вживає таких законодавчих та інших заходів, які можуть знадобитися для того, щоб визнати в якості кримінально ка- 
раних такі діяння, коли вони вчиняються навмисно: обидва чи одне 3 таких діянь, не відносячи їх до замаху на вчинення злочину і незалежно від фактичного вчинення злочинного діяння (змова з одним або декількома особами щодо вчинення серйозного злочину, що переслідує мету, прямо чи посередньо пов'язану з одержанням фінансової або іншої матеріальної вигоди, причому, якщо це передбачено внутрішнім законодавством, також передбачається фактичне вчинення одним з учасників змови будь-якої дії для реалізації цієї змови або причетність організованої злочинної групи; діяння будь-якої особи, яка, усвідомлюючи або мету і загальну злочинну діяльність організованої злочинної групи, або її наміри вчинити відповідні злочини, бере активну участь у: злочинній діяльності організованої злочинної групи; інших видах діяльності організованої злочинної групи, усвідомлюючи, що її участь сприятиме досягненню вищезгаданої злочинної мети; організацію, керівництво, пособництво, підбурювання, сприяння або надання порад щодо серйозного злочину, вчиненого за участю організованої злочинної групи) [2].

При чому, усвідомлення, намір, умисел, мета або змова, про які зазначено вище, можуть бути встановлені з об'єктивних фактичних обставин справи.

Держави-учасниці, внутрішнє законодавство яких як елемент складів злочинів, визнаних такими що, передбачає причетність організованої злочинної групи, забезпечують, щоб їхнє внутрішнє законодавство відносило до числа серйозних злочинів усі злочини, вчинені за участю організованих злочинних груп.

Згідно Угоди між Україною та Європейським поліцейським офісом про оперативне та стратегічне співробітництво 2016 року компетенція Європолу поширюється на боротьбу з організованою злочинністю, тероризмом та іншими формами тяжких злочинів, які перелічені нижче і зачіпають дві або більше держави-члени у такий спосіб, що потребує спільного підходу держав-членів, зважаючи на масштаб, значущість та наслідки таких злочинів [3].

До таких тяжких злочинів відносять: незаконний обіг наркотиків; нелегальна діяльність, пов'язана 3 відмиванням коштів; злочин, пов'язаний з ядерними та радіоактивними речовинами; нелегальне перевезення іммігрантів; торгівля людьми; злочин, пов'язаний з ав- 
тотранспортними засобами; вбивство, заподіяння тяжких тілесних ушкоджень; нелегальна торгівля людськими органами і тканинами; викрадення людей, незаконне обмеження свободи та взяття заручників; расизм та ксенофобія; організоване пограбування; нелегальна торгівля предметами, що становлять культурну цінність, зокрема антикваріатом та виробами мистецтва; обман та шахрайство; рекет та вимагання; підробка продукції та її піратське розповсюдження; підробка адміністративних документів та їх незаконний обіг; підробка грошових знаків та платіжних засобів; злочин з використанням комп'ютера; корупція; нелегальна торгівля зброєю, боєприпасами та вибухівкою; нелегальна торгівля видами тварин, які перебувають під загрозою зникнення; нелегальна торгівля видами рослин, які перебувають під загрозою зникнення, та їхніх підвидів; злочин проти навколишнього середовища; нелегальна торгівля гормональними речовинами та іншими стимуляторами росту.

\section{3. Визначення злочинів з ознаками транснаціональної злочинності за національним законодавством}

Кримінальні правопорушення, які можуть мати ознаки транснаціональних зв'язків за КК України: умисне вбивство, ст. 115 КК України, у тому числі вчинені на замовлення п. 11 ч. 2 ст. 115 КК України; захоплення заручників, ст. 147 КК України; торгівля людьми, ст. 149 КК України; крадіжка, ст. 185 КК України, у тому числі в особливо великих розмірах або вчинена організованою групою, ч. 5 ст. 185 КК України; грабіж, ст. 186 КК України; розбій, ст. 187 КК України; вимагання, ст. 189 КК України; привласнення, розтрата майна або заволодіння ним шляхом зловживання службовим становищем, ст. 191 КК України, у тому числі в особливо великих розмірах, ч. 5 ст. 191 КК України; виготовлення, зберігання, придбання, перевезення, пересилання, ввезення в Україну з метою використання при продажу товарів, збуту або збут підроблених грошей, державних цінних паперів, білетів державної лотереї, марок акцизного податку чи голографічних захисних елементів, ст. 199 КК України; контрабанда, ст. 201 КК України; незаконне виготовлення, зберігання, збут або транспортування 3 метою збуту підакцизних товарів, ст. 204 КК України; протидія законній господарській діяльності, ст. 206 КК України; легалізація (відмивання) 
майна одержаного злочинним шляхом, ст. 209 КК України; нецільове використання бюджетних коштів, здійснення видатків бюджету чи надання кредитів з бюджету без встановлених бюджетних призначень або з їх перевищенням, ст. 210 КК України; ухилення від сплати податків, зборів (обов'язкових платежів), ст. 212 КК України; шахрайство 3 фінансовими ресурсами, ст. 222 КК України; порушення правил охорони або використання надр, ст. 240 КК України; незаконне видобування, збут, придбання, передача, пересилання, перевезення, переробка бурштину, ст. $240^{1}$ КК України; незаконна порубка або незаконне перевезення, зберігання, збут лісу, ст. 246 КК України; створення, керівництво злочинною спільнотою або злочинною організацією, а також участь у ній, ст. 255 КК України; бандитизм, ст. 257 КК України; терористичний акт, ст. 258 КК України; фінансування тероризму, ст. $258^{5}$ КК України; незаконний обіг зброї, ст. ст. 262, 263, $263^{1}$ КК України; контрабанда наркотичних засобів, психотропних речовин, їх аналогів чи прекурсорів, або фальсифікованих лікарських засобів, ст. 305 КК України; використання коштів, здобутих від незаконного обігу наркотичних засобів, психотропних речовин, їх аналогів, прекурсорів, отруйних чи сильнодіючих речовин або отруйних чи сильнодіючих лікарських засобів, ст. 306 КК України; злочини у сфері обігу наркотичних засобів, психотропних речовин, їх аналогів або прекурсорів та інші злочини проти здоров'я населення, ст. ст. 307-327 КК України; незаконне переправлення осіб через державний кордон України, ст. 332 КК України; примушування до виконання чи невиконання цивільно-правових зобов'язань, ст. 355 КК України; отримання неправомірної вигоди, ст. ст. 368-370 КК України.

Крім того, до вищезазначеного переліку можуть входити і інші види кримінальних правопорушень відповідно до конкретної ситуації.

Так, наприклад, 14.02.2014 року Тернопільський міськрайонний суд Тернопільської області у відкритому судовому засіданні розглядав справу про обвинувачення у вчиненні кримінальних правопорушень, передбачених ч. 1 ст. 255 КК України, ч. 3 ст. 305КК України (в редакції від 05.07.2012 року), ч. 3 ст. 307 КК України (в редакції від 06.10.2011 року) [4]. Обвинувачений упродовж 2010-2011 років встановив та налагодив зв'язки з громадянами Республіки Польща та Республіки Еквадор, які вчиняють злочини в сфері незаконного обігу 
наркотичних засобів, під виглядом здійснення міжнародної підприємницької діяльності. Зокрема, обвинувачений дізнався про способи та методи незаконного придбання, переміщення через митні кордони та канали збуту наркотичних засобів. Усвідомлюючи, що цей вид незаконної діяльності є високоприбутковим, оскільки вартість кокаїну у Європі набагато вища, ніж у країнах Південної Америки та використовуючи здобутий досвід, обвинувачений дійшов висновку про необхідність створення злочинної організації та залучити до неї громадян різних країн світу між якими чітко розподілити ролі. Для реалізації мети створення злочинної організації, обвинувачений вступив у злочинну змову з іншою особою громадянином Республіки Польща, матеріали відносно якого виділені в окреме провадження, та разом із ним розробили єдиний план учинення злочинів пов'язаних з незаконним обігом наркотичних засобів.

Особу обвинуваченого судом було визнано винним у вчиненні кримінальних правопорушень передбачених ч. 1 ст. 255 КК України, ч. 3 ст. 305 КК України (в редакції від 05.07.2012 року), ч. 3 ст. 307 КК України (в редакції від 06.10.2011 року) і призначено йому покарання: за ч. 1 ст. 255 КК України - 6 (шість) років позбавлення волі; за ч. 3 ст. 305 КК України (в редакції від 05.07.2012 року) із застосуванням ч. 1 ст. 69 КК України - 8 (вісім) років позбавлення волі з конфіскацією наркотичних засобів, що були предметом контрабанди, та з конфіскацією всього належного йому на праві власності майна; за ч. 3 ст. 307 КК України (в редакції від 06.10.2011 року) із застосуванням ч. 1 ст. 69 КК України - 7 (сім) років позбавлення волі з конфіскацією всього належного йому на праві власності майна.

Слід також звернути увагу на існування компромісу між державою та особою, яка вчинила певне із зазначених вище кримінальних правопорушень, яке знаходить свій прояв у можливості застосування до таких осіб звільнення від кримінальної відповідальності. Застосування цього пільгового інституту здійснюється за дотримання відповідних умов, передбачених Особливою частиною Кримінального кодексу України.

Таким чином, відповідно до: ч. 4 cm. 212 «хилення від сплати податків, зборів (обов'язкових платежів)» КК України «Особа, яка вчинила діяння, передбачені частинами першою, другою, або діяння, передбачені частиною третьою (якщо вони призвели до фактичного 
ненадходження до бюджетів чи державних цільових фондів коштів в особливо великих розмірах) ст. 212 КК України, звільняється від кримінальної відповідальності, якщо вона до притягнення до кримінальної відповідальності сплатила податки, збори (обов'язкові платежі), а також відшкодувала шкоду, завдану державі їх несвоєчасною сплатою (фінансові санкції, пеня)»; ч. 6 cm. 255 «Створення, керівництво злочинною спільнотою або злочинною організачією, а також участь у ній» «Звільняється від кримінальної відповідальності особа, крім організатора або керівника злочинної організації, за вчинення злочину, передбаченого частиною другою або третьою ст. 255 КК України, якщо вона до повідомлення їй про підозру у вчиненні цього злочину добровільно повідомила про створення злочинної організації або участь у ній та активно сприяла її розкриттю»; ч. $6 \mathrm{~cm} .258$ «Терористичний aкm» «Особа звільняється від кримінальної відповідальності за діяння, передбачене частиною першою цієї статті в частині погрози вчинення терористичного акту, якщо вона до повідомлення їй про підозру у вчиненні нею злочину добровільно повідомила правоохоронний орган про цей злочин, сприяла його припиненню або розкриттю, у разі якщо внаслідок цього і вжитих заходів було відвернено небезпеку для життя чи здоров'я людини або заподіяння значної майнової шкоди чи настання інших тяжких наслідків, якщо в ії діях немає складу іншого злочину»; ч. 4 cm. $258^{5}$ «Фінансування тероризму» «Особа, крім організатора або керівника терористичної групи (організаціі), звільняється від кримінальної відповідальності за дії, передбачені цією статтею, якщо вона добровільно до притягнення до кримінальної відповідальності повідомила про відповідну терористичну діяльність або іншим чином сприяла її припиненню або запобіганню злочину, який вона фінансувала або вчиненню якого сприяла, за умови, що в її діях немає складу іншого злочину»; ч. $3 \mathrm{~cm} .263$ «Незаконне поводження зі зброєю, бойовими припасами або вибуховими речовинами» «Звільняється від кримінальної відповідальності особа, яка вчинила злочин, передбачений частинами першою або другою цієї статті, якщо вона добровільно здала органам влади зброю, бойові припаси, вибухові речовини або вибухові пристрої»; ч. $4 \mathrm{~cm} .307$ «Незаконне виробництво, виготовлення, придбання, зберігання, перевезення, пересилання чи збут наркотичних засобів, психотропних речовин або їх аналогів» «Особа, 
яка добровільно здала наркотичні засоби, психотропні речовини або їх аналоги і вказала джерело їх придбання або сприяла розкриттю кримінальних правопорушень, пов'язаних з їх незаконним обігом, звільняється від кримінальної відповідальності за незаконне їх виробництво, виготовлення, придбання, зберігання, перевезення, пересилання (частина перша цієї статті, частина перша статті 309 КК України)»; 4. $4 \mathrm{~cm} .309$ «Незаконне виробництво, виготовлення, придбання, зберігання, перевезення чи пересилання наркотичних засобів, психотропних речовин або їх аналогів без мети збуту» «Особа, яка добровільно звернулася до лікувального закладу і розпочала лікування від наркоманії, звільняється від кримінальної відповідальності за дії, передбачені частиною першою цісї статті 309 КК України»; ч. 4 cm. 311 «Незаконне виробництво, виготовлення, придбання, зберігання, перевезення чи пересилання прекурсорів» «Особа, яка добровільно здала прекурсори, що призначалися для виробництва або виготовлення наркотичних засобів чи психотропних речовин, і вказала джерело їх придбання або сприяла розкриттю кримінальних правопорушень, пов'язаних із незаконним обігом прекурсорів, наркотичних засобів, психотропних речовин або їх аналогів, звільняється від кримінальної відповідальності за незаконні їх виробництво, виготовлення, придбання, зберігання, перевезення, пересилання (частина перша статті 311 КК України)»; ч. $5 \mathrm{~cm} .321$ «Heзаконне виробництво, виготовлення, придбання, перевезення, пересилання, зберігання з метою збуту або збут отруйних чи сильнодіючих речовин або отруйних чи сильнодіючих лікарських засобів» «Особа, яка добровільно здала отруйні чи сильнодіючі речовини, що не є наркотичними або психотропними чи їх аналогами, або отруйні чи сильнодіючі лікарські засоби та вказала джерело їх придбання або сприяла розкриттю злочинів, пов'язаних з їх незаконним обігом, звільняється від кримінальної відповідальності за незаконне виробництво, виготовлення, придбання, перевезення, пересилання, зберігання отруйних чи сильнодіючих речовин, що не є наркотичними або психотропними чи їх аналогами, або отруйних чи сильнодіючих лікарських засобів, а також за вчинення таких дій без спеціального на те дозволу (частина перша статті 321 КК України) щодо обладнання, призначеного для виробництва чи виготовлення отруйних чи сильнодіючих речовин, що не $є$ наркотичними або психотропними чи їх аналогами, або отруйних 
чи сильнодіючих лікарських засобів»; ч. 4 cm. 321 «Фальсифікащія лікарських засобів або обіг фальсифікованих лікарських засобів» «Особа, яка добровільно здала фальсифіковані лікарські засоби та вказала джерело їх придбання або сприяла розкриттю злочинів, пов'язаних з їх обігом, звільняється від кримінальної відповідальності за придбання, перевезення, пересилання чи зберігання з метою збуту, збут завідомо фальсифікованих лікарських засобів, їх ввезення на територію України, вивезення з території України, транзит через іiї територію (частина перша статті $321^{1}$ КК України, якщо такі дії не створили загрози для життя чи здоров'я людей)».

Тож, варто зазначити, що в КК України йдеться про транснаціональну злочинність лише в одній статті - ч. 5 ст. 143 КК «Порушення встановленого законом порядку трансплантації анатомічних матеріалів людини», де визначено як особливо кваліфікуючу ознаку - порушення встановленого законом порядку застосування трансплантації анатомічних матеріалів людини, що спричинило істотну шкоду здоров'ю потерпілого. Однак, роз'яснення щодо транснаціональних організацій, які займаються незаконною трансплантацією анатомічних матеріалів людини не дається.

До транснаціональних організацій у ч. 5 ст. 143 належать організації, які систематично займаються вилученням у людей шляхом примушування або обману їх органів чи тканин з метою їх трансплантації реципієнтам, які перебувають в інших країнах, та/або міжнародною незаконною торгівлею органами чи тканинами живих чи померлих людей. Заборона розглядати людське тіло і його частини як предмет комерційних операцій $є$ всесвітньо визнаним принципом трансплантації органів і тканин людини, але незаконність стосовно торгівлі вказаними предметами у разі вчинення цих діянь на території України визначається відповідно до законодавства України [5].

\section{4. Визначення злочинів з ознаками транснаціональних зв'язків: порівняльна характеристика}

Для порівняння, деякі зарубіжні країни також регламентують можливість застосування звільнення від кримінальної відповідальності за подібні, вітчизняному закону про кримінальну відповідальність, кримінальні правопорушення. 
Так, Кримінальний кодекс Республіки Казахстан у примітці до cm. 244 «Ухилення громадянина від сплати податку $i$ (або) інших обов'язкових платежів до бюджету» $K K ~ P K$ визначає, що особа, яка вчинила діяння, передбачене статтею 244 КК РК, звільняється від кримінальної відповідальності в разі добровільної сплати заборгованості по податках і (або) інших обов'язкових платежах до бюджету, а також пені, встановлених законодавством Республіки Казахстан; cm. 262 «Створення $і$ керівництво організованою групою, злочинною організацією, а так само участь у них» $K K ~ P K$ - особа, яка добровільно припинила участь в злочинній групі і активно сприяла розкриттю чи припиненню злочинів, скоєних або вчинених злочинною групою, звільняється від кримінальної відповідальності, якщо в ії діях не міститься складу іншого злочину; cm. 255 «Акт тероризму» $К К ~ P K-$ особа, яка бере участь у підготовці акту тероризму, звільняється від кримінальної відповідальності, якщо вона своєчасним попередженням державних органів або іншим способом сприяла запобіганню акту тероризму і якщо в іiі діях не міститься складу іншого злочину; $\mathrm{cm} .258$ «Фінансування терористичної або екстремістської діяльності і інше пособництво тероризму або екстремізму» $K K ~ P K$ - особа, яка здійснює фінансування терористичної або екстремістської діяльності і інше пособництво тероризму або екстремізму під загрозою насильства i добровільно заявила про це, а також активно сприяла розкриттю чи припиненню злочину, звільняється від кримінальної відповідальності, якщо в іiі діях не міститься складу іншого злочину; cm. 287 «Незаконні придбання, передача, збут, зберігання, перевезення або носіння зброї, боєприпасів, вибухових речовин і вибухових пристроїв КК РК - особа, яка добровільно здала предмети, зазначені у цій статті, звільняється від кримінальної відповідальності, якщо в їі діях не міститься складу іншого злочину. Не визнається добровільною здача предметів, зазначених у цій статті, в разі їх вилучення при затриманні особи, а також при провадженні слідчих дій по їх виявленню та вилученню; cm. 296 «Незаконне поводження з наркотичними засобами, психотропними речовинами, їх аналогами без мети збуту» КК РК - особа, яка добровільно здала наркотичні засоби, психотропні речовини, їх аналоги, прекурсори, придбані нею для особистого споживання, або добровільно звернулася до медичного закладу за наданням медичної допомоги 
у зв'язку зі вживанням наркотичних засобів, психотропних речовин, ïx аналогів в немедичних цілях, або активно сприяла розкриттю чи припиненню злочинів, пов'язаних з незаконним обігом наркотичних засобів, психотропних речовин, їх аналогів, прекурсорів, викриттям осіб, які їх вчинили, виявленням майна, здобутого злочинним шляхом, звільняється від кримінальної відповідальності за ст. 296 КК РК [6].

Кримінальний кодекс Азербайджанскої Республіки у примітці до cm. 214 «Тероризм» визначає, що особа, яка брала участь у підготовці терористичного діяння, звільняється від кримінальної відповідальності у разі, якщо, своєчасно попередить органи влади, або іншим способом надасть допомогу запобіганню подібного діяння, з умовою, що в її діяннях не має складу іншого злочину; cm. $214^{1}$ «Фінансування тероризму»особа, яка вчинила діяння, передбачене статтею $214^{1}$ КК РА, яка надала допомогу в запобіганні подібного терористичного діяння шляхом своєчасного повідомлення органів влади або іншим способом, звільняється від кримінальної відповідальності за відсутності в їі діянні складу іншого злочину; cm. 228 «Незаконні придбання, передача, збут, зберігання, перевезення або носіння зброї, комплектуючих деталей до неї, боєприпасів, вибухових речовин і вибухових пристроїв» - особа, яка добровільно здала предмети, зазначені у цій статті, звільняється від кримінальної відповідальності, якщо в їі діях не міститься інший склад злочину; cm. 234 «Незаконні виробництво, виготовлення, придбання, зберігання, перевезення, пересилання чи збут наркотичних засобів, психотропних речовин або їх прекурсорів» - особа, яка добровільно здала наркотичні засоби, психотропні речовини або їх прекурсори і активно сприяла розкриттю чи припиненню злочинів, пов'язаних 3 незаконним обігом наркотичних засобів, психотропних речовин або їх прекурсорів, викриттям осіб, які їх вчинили, виявленням майна, здобутого злочинним шляхом, звільняється від кримінальної відповідальності за даний злочин [7].

Кримінальний кодекс Грузії у примітці до cm. 223 «Створення незаконного формування, керівництво їм, членство, участь у такому формуванні або (i) здійснення іншої діяльності на користь незаконного формування» закріплено, що особа, яка добровільно припинила діяння, передбачене цією статтею, і здала предмет, зазначений у частині першій примітки до ст. 223 КК Грузії (у разі володіння ним), звільняється від кримінальної відповідальності, якщо ії діяння зовсім позбавлене ознак іншого злочину [8]. 
Кримінальний кодекс Республіки Молдова у ч. 5 cm. 217 «Незаконний обіг наркотиків, етноботанічних засобів або їх аналогів не з метою відчуження» визначено, що особа, яка вчинила дії, передбачені ст. 217 або 217 звільняється від кримінальної відповідальності у разі, якщо вона активно сприяла виявленню або запобіганню злочину, пов'язаного з незаконним обігом наркотиків, етноботанічних засобів або їх аналогів, за допомогою явки з повинною, добровільної здачі наркотичних, психотропних речовин або їх аналогів, посилання на джерело придбання даних речовин, встановленню осіб, що сприяли вчиненню злочину, виявленню грошових коштів, майна та доходів, отриманих внаслідок вчинення злочину. Не може вважатися добровільною здачею наркотиків, етноботанічних засобів або їх аналогів вилучення даних речовин при затриманні особи, а також при здійсненні дій кримінального переслідування за їх виявлення та вилучення; ч. 6 cm. 278 «Терористичний акт»-особа, яка брала участь у підготовці терористичного акту, звільняється від кримінальної відповідальності, якщо вона своєчасним попередженням органів влади або іншим шляхом сприяла запобіганню здійснення терористичного акту і якщо в діях цієї особи немає іншого складу злочину; $4.3 \mathrm{~cm} .290$ «Незаконне носіння, зберігання, придбання, виготовлення, ремонт або збут зброї $і$ боєприпасів, їx розкрадання» - особа, яка добровільно здала вогнепальну зброю або боєприпаси, які зберігалися у неї без відповідного дозволу, звільняється від кримінальної відповідальності [9].

Кримінальний кодекс Туркменістану у примітці до $\mathrm{cm} .271^{1}$ «Фінансування тероризму» містить наступне, - особа, яка вчинила злочин, передбачений цією статтею, в результаті застосування або загрози застосування до неї насильства, звільняється від кримінальної відповідальності, якщо вона своєчасно повідомила про це в органи державної влади, сприяла запобіганню і розкриттю злочину, і в її діях не міститься склад іншого злочину; cm. 275 «Створення організованої групи, злочинного співтовариства і інших злочинних структур або участь у їх діяльності» особа, яка вчинила злочин, передбачений цією статтею, звільняється від кримінальної відповідальності, якщо вона добровільно припинила злочинні дії, сприяла запобіганню, виявленню таких, що готуються, вчиняються або вчинених злочинів, і в іiі діях не міститься склад іншого злочину; cm. 287 «Незаконне придбання, збут, зберігання, перевезення, пересилання чи носіння зброї, боєприпасів, вибухових речовин або вибу- 
хових пристроїв» - особа, яка добровільно здала предмети, зазначені у цій статті, звільняється від кримінальної відповідальності, якщо в їі діях не міститься іншого складу злочину; cm. 292 «Незаконне виготовлення, переробка, придбання, зберігання, перевезення, пересилання наркотичних засобів або психотропних речовин з метою збуту» - особа, яка добровільно здала наркотичні засоби або психотропні речовини і активно сприяла розкриттю чи припиненню злочинів, пов'язаних з незаконним обігом наркотичних засобів або психотропних речовин, викриттям осіб, які їх вчинили, виявленням майна, здобутого злочинним шляхом, звільняється від кримінальної відповідальності за діяння, передбачені частинами першою або другою цієї статті; cm. 293 «Незаконне виготовлення, переробка, придбання, зберігання, перевезення чи пересилання наркотичних засобів або психотропних речовин без мети збуту» - особа, яка добровільно здала наркотичні засоби або психотропні речовини і активно сприяла розкриттю чи припиненню злочинів, пов'язаних $з$ незаконним обігом наркотичних засобів або психотропних речовин, викриттям осіб, які їх вчинили, виявленням майна, здобутого злочинним шляхом звільняється від кримінальної відповідальності за даний злочин [10].

Кримінальний кодекс Таджикистану у примітці до $\mathrm{cm} .179$ «Тероризм» містить наступні положення, - особа, яка брала участь у підготовці акту тероризму, звільняється від кримінальної відповідальності, якщо вона своєчасним попередженням органів влади або іншим способом сприяла запобіганню здійснення акту тероризму і якщо в діях цієї особи не міститься іншого складу злочину; $\mathrm{cm} .187$ «Організація злочинного співтовариства (злочинної організації)» - особа, яка добровільно заявила органам влади про участь у злочинному співтоваристві (злочинній організації) і сприяла припиненню його діяльності, звільняється від кримінальної відповідальності, якщо в іiї діях не міститься іншого складу злочину; ст. 195 «Незаконне придбання, передача, збут, зберігання, транспортування або носіння зброї, боєприпасів, вибухових речовин $і$ вибухових пристроїв» - особа, яка добровільно здала предмети, зазначені у цій статті, звільняється від кримінальної відповідальності, якщо в їі діях не міститься іншого складу злочину [11].

Кримінальний кодекс Киргизстану у примітці до cm. 239 «Акт тероризму» закріплює, що особа, яка брала участь у підготовці акту тероризму, звільняється від кримінальної відповідальності за діяння, передбачені 
цією статтею, якщо вона своєчасним попередженням органів влади або іншим способом сприяла запобіганню акту тероризму; $\mathrm{cm} .248$ «Створення організованої групи або участь у ній» - особа, яка добровільно припинила участь в організованій групі і яка повідомила відповідним органам державної влади відомості, що викривають інших осіб у створенні такої групи, керівництві нею або участі у ній, звільняється від кримінальної відповідальності за участь в організованій групі; cm. 249 «Створення злочинної організащії або участь у ній» - особа, яка добровільно припинила участь у злочинній організації і яка повідомила відповідним органам державної влади відомості, що викривають інших осіб у створенні такої організації, керівництві нею або входять до неї підрозділами або участі у ній, а також у створенні об'єднання організаторів, керівників чи інших представників організованих груп, звільняється від кримінальної відповідальності за участь у злочинній організації; cm. 253 «Незаконний обіг зброї, боєприпасів» - особа, яка добровільно здала предмети, зазначені у цій статті, звільняється від кримінальної відповідальності за діяння, передбачене цією статтею; cm. 254 «Незаконне виготовлення зброї» - особа, яка добровільно здала предмети, зазначені у цій статті, звільняється від кримінальної відповідальності за діяння, передбачені цією статтею; cm. 267 «Незаконне виготовлення наркотичних засобів, психотропних речовин $і$ їх аналогів 3 метою збуту» - особа, яка вчинила злочин, передбачений цією статтею, яка добровільно здала наркотичні засоби, психотропні речовини або їх аналоги і активно сприяла розкриттю чи припиненню злочинів, пов'язаних з незаконним обігом наркотичних засобів, психотропних речовин або їх аналогів, викриттям осіб, які їх вчинили, виявленням майна, здобутого злочинним шляхом, звільняється від кримінальної відповідальності за діяння, передбачене цією статтею [12].

Кримінальний кодекс Республіки Арменія у ч. 4 cm. 217 «Тероризм» визначає, що особа, яка брала участь у підготовці акту тероризму, звільняється від кримінальної відповідальності, якщо вона своєчасним повідомленням органам влади або іншим способом сприяла припиненню акту тероризму і якщо іiі дії не містять іншого складу злочину; ч. $4 \mathrm{~cm} .223$ «Створення злочинного співтовариства або участь у злочинному співтоваристві» - особа, яка добровільно заявила державним органам про створення ним злочинного співтовариства, або про керівництво злочинним співтовариством, або про участь у злочинному співтоваристві, і сприяла 
припиненню його діяльності, звільняється від кримінальної відповідальності, якщо їі дії не містять іншого складу злочину; ч. $5 \mathrm{~cm}$. 235 «Незаконні придбання, збут, зберігання, перевезення або носіння зброї, боєприпасів, вибухових речовин або вибухових пристроїв - особа, яка добровільно здала предмети, зазначені у цій статті, звільняється від кримінальної відповідальності, якщо іiі дії не містять іншого складу злочину; ч. 4 cm. 236 «Незаконне виготовлення зброї» - особа, яка добровільно здала предмети, зазначені у цій статті, звільняється від кримінальної відповідальності, якщо іiі дії не містять іншого складу злочину; ч. 6 cm. 266 «Незаконний обіг наркотичних засобів або психотропних речовин з метою збуту» - особа, яка добровільно здала наркотичні засоби або психотропні речовини, звільняється від кримінальної відповідальності за незаконні виготовлення, переробку, придбання, зберігання, перевезення чи пересилання або незаконний збут наркотичних засобів або психотропних речовин [13].

\section{5. Висновки}

3 огляду на проведений аналіз стану визначення злочинів з ознаками транснаціональних зв'язків ми можемо побачити доволі великий перелік злочинів, які можуть мати ознаки транснаціональної злочинності. Однак, деякі визначені у списку злочини не відповідають диспозиції статті КК України або взагалі відсутня така норма, незважаючи на підписані договори та ратифіковані конвенції щодо протидії транснаціональній злочинності. Наприклад, «расизм та ксенофобія» визначаються в КК України лише в якості кваліфікуючої ознаки, а не окремого складу злочину, «злочин з використанням комп'ютера» теж використовується як кваліфікуюча ознака до деяких статей Особливої частини КК України, які знаходяться до того ж в різних розділах. Також, «нелегальна торгівля видами тварин, які перебувають під загрозою зникнення»; «нелегальна торгівля видами рослин, які перебувають під загрозою зникнення, та їхніх підвидів»; «нелегальна торгівля гормональними речовинами та іншими стимуляторами росту», - не є кримінально караними за національним законом про кримінальну відповідальність.

Слід зазначити, що одним із способів протидії транснаціональній злочинності є застосування засобів кримінально-правового впливу на суб'єктів. Така прогалина в законодавстві значно знижує ефективність протидії транснаціональній злочинності. 
Найбільшу кількість злочинів, які можуть мати ознаки транснаціональної злочинності становлять діяння, пов'язані з незаконним обігом наркотичних засобів, торгівлею людьми, контрабандою, а також економічні злочини, та інші види злочинів, які тісно пов'язані з перетином кордону. Отже, можемо зазначити, що до КК України необхідно додати як кваліфікуючу ознаку: «...вчинені злочинними групами $з$ транснаціональними зв'язками».

Наприклад, диспозицію ч. 2 ст. 201 КК України можна викласти наступним чином: «2. Та сама дія, вчинена за попередньою змовою групою осіб або особою, раніше судимою за злочин, передбачений цією статтею, або службовою особою з використанням службового становища, або злочинною групою з транснаціональними зв'язками».

\section{Список літератури:}

1. Звіт про результати боротьби з організованими групами та злочинними організаціями за грудень 2016, 2017, 2018, 2019, 2020 років. URL: https://old.gp.gov.ua/ua/stst2011.html?dir_id=114143\&libid=100820\&c=edit \&_c=fo (дата звернення: 12.03.2021).

2. Конвенція Організації Об'єднаних Націй проти транснаціональної організованої злочинності, Прийнята резолюцією 55/25 Генеральної Асамблеї від 15 листопада 2000 року, ратифіковано із застереженнями і заявами Законом № 1433-IV від 04.02.2004 року. URL: https://zakon.rada.gov.ua/laws/ show/995_789\#Text (дата звернення: 21.04.2021).

3. Угода між Україною та Європейським поліцейським офісом про оперативне та стратегічне співробітництво. URL: https://zakon.rada.gov.ua/laws/ show/984_001-16\#n156 (дата звернення: 21.04.2021).

4. Вирок Тернопільського міськрайонного суду Тернопільської області від 14.02.2014 року. URL: https://reyestr.court.gov.ua/Review/37687995

5. Науково-практичний коментар Кримінального кодексу України / за ред. M.I. Мельника, М.I. Хавронюка. Київ : Дакор, 2018. 1360 с.

6. Уголовный кодекс Республики Казахстан : Закон Республики Казахстан от 03.07.2014 г. № 226-V (с изменениями и дополнениями по состоянию на 30.12.2020 г.). URL: https://online.zakon.kz/document/?doc_id=31575252 (дата звернення: 10.04.2021).

7. Уголовный кодекс Азербайджанской Республики : Закон Азербайджанской Республики от 30 декабря 1999 года № 787-IQ (с изменениями и дополнениями по состоянию на 06.10.2020 г.). URL: http://continent-online.com/ Document $/$ doc_id $=30420353 \&$ doc_id $2=30420353 \#$ pos $=5 ;-102 \&$ pos $2=2881 ;-80$ (дата звернення: 10.04.2021).

8. Уголовный кодекс Грузии : Закон Грузии от 22.07.1999 г. № 2287. URL: https://matsne.gov.ge/ru/document/view/16426?publication=229 (дата звернення: 10.04.2021). 
9. Уголовный кодекс Республики Молдова : Закон Республики Молдова от 18.04.2002 г. № 985-XV (с изменениями и дополнениями по состоянию на 16.12.2020 г.). URL: http://continent-online.com/Document/?doc_id=30394923 (дата звернення: 10.04.2021).

10. Уголовный кодекс Туркменистана : Закон Туркменистана от 12.06 .1997 г. № 222-I (с изменениями и дополнениями по состоянию на 22.08.2020г.). URL: https://online.zakon.kz/document/?doc id=31295286 (дата звернення: 10.04.2021).

11. Уголовный кодекс Республики Таджикистан : Закон Республики Таджикистан от 21.05.1998 г. № 574 (с изменениями и дополнениями по состоянию на 17.12.2020 г.). URL: http://continent-online.com/Document/?doc_id=30397325 (дата звернення: 10.04.2021).

12. Уголовный кодекс Кыргызской Республики : Закон Кыргызской Республики от 02.02.2017 г. № 19 (с изменениями и дополнениями по состоянию на 31.12.2020 г.). URL: http://cbd.minjust.gov.kg/act/view/ru-ru/111527 (дата звернення: 10.04.2021).

13.Уголовный кодекс Республики Армения : Закон Республики Армения от 18.04.2003 г. URL: http://www.parliament.am/legislation.php?sel=show \&ID=1349\&lang=rus (дата звернення: 10.04.2021).

\section{References:}

1. Zvit pro rezultaty borotby $\mathrm{z}$ orhanizovanymy hrupamy ta zlochynnymy orhanizatsiiamy za hruden 2016, 2017, 2018, 2019, 2020 rokiv [Report on the results of the fight against organized groups and criminal organizations for December 2016, 2017, 2018, 2019, 2020]. Retrieved from: https://old.gp.gov.ua/ua/stst2011. html?dir_id=114143\&libid=100820\&c=edit\&_c=fo (accessed 12 March 2021).

2. Konventsiia Orhanizatsii Obiednanykh Natsii proty transnatsionalnoi orhanizovanoi zlochynnosti, Pryiniata rezoliutsiieiu 55/25 Heneralnoi Asamblei vid 15 lystopada 2000 roku, ratyfikovano iz zasterezhenniamy i zaiavamy Zakonom № 1433-IV vid 04.02.2004 roku [United Nations Convention against Transnational Organized Crime, adopted by General Assembly resolution 55/25 of 15 November 2000, ratified with reservations and declarations by Law № 1433-IV of 4 February 2004]. Retrieved from: https://zakon.rada.gov.ua/laws/show/995_789\#Text (accessed 21 April 2021)

3. Uhoda mizh Ukrainoiu ta Yevropeiskym politseiskym ofisom pro operatyvne ta stratehichne spivrobitnytstvo [Agreement between Ukraine and the European Police Office on operational and strategic cooperation]. Retrieved from: https://zakon.rada.gov.ua/laws/show/984_001-16\#n156 (accessed 21 April 2021).

4. Vyrok Ternopilskoho miskraionnoho sudu Ternopilskoi oblasti vid 14.02.2014 roku [Judgment of the Ternopil City District Court of the Ternopil region of 14.02.2014]. Retrieved from: https://reyestr.court.gov.ua/Review/37687995 (accessed 21 April 2021).

5. Naukovo-praktychnyi komentar Kryminalnoho kodeksu Ukrainy za red. M.I. Melnyka, M.I. Khavroniuka (2018) [Scientific and practical commentary on the Crimean Code of Ukraine] Dakor, 10-te vyd., pererobl. ta dopov. Kyiv, p. 1360. 
6. Ugolovnyj kodeks Respubliki Kazahstan: Zakon Respubliki Kazahstan ot 03.07.2014 g. № 226-V (s izmeneniyami i dopolneniyami po sostoyaniyu na 30.12 .2020 g.) [The Criminal Code of the Republic of Kazakhstan: Law of the Republic of Kazakhstan dated 03.07.2014 No. 226-V (with amendments and additions as of 30.12.2020)]. Retrieved from: https://online.zakon.kz/document/?doc_ $\mathrm{id}=31575252$ (accessed 10 April 2021).

7. Ugolovnyj kodeks Azerbajdzhanskoj Respubliki: Zakon Azerbajdzhanskoj Respubliki ot 30 dekabrya 1999 goda № 787-IQ (s izmeneniyami i dopolneniyami po sostoyaniyu na 06.10.2020 g.) [Criminal Code of the Republic of Azerbaijan: Law of the Republic of Azerbaijan dated December 30, 1999 No. 787-IQ (with amendments and additions as of 06.10.2020)]. Retrieved from: http://continent-online.com/Document/?doc_id=30420353\&doc_id $2=30420353 \#$ pos $=5 ;-102 \& \operatorname{pos} 2=2881 ;-80($ accessed 10 April 2021).

8. Ugolovnyj kodeks Gruzii: Zakon Gruzii ot 22.07.1999 g. № 2287 [Criminal Code of Georgia: Law of Georgia dated July 22, 1999 No. 2287]. Retrieved from: https://matsne.gov.ge/ru/document/view/16426?publication=229 (accessed 10 April 2021).

9. Ugolovnyj kodeks Respubliki Moldova: Zakon Respubliki Moldova ot 18 April 2002 g. № 985-XV (s izmeneniyami i dopolneniyami po sostoyaniyu na 16.12.2020 g.) [Criminal Code of the Republic of Moldova: Law of the Republic of Moldova dated April 18, 2002 No. 985-XV (with amendments and additions as of December 16, 2020)]. Retrieved from: http://continent-online.com/ Document/?doc_id=30394923 (accessed 10 April 2021).

10. Ugolovnyj kodeks Turkmenistana: Zakon Turkmenistana ot $12.06 .1997 \mathrm{~g}$. № 222-I (s izmeneniyami i dopolneniyami po sostoyaniyu na 22.08 .2020 g.) [Criminal Code of Turkmenistan: Law of Turkmenistan of 12.06.1997, No. 222-I (with amendments and additions as of 22.08.2020)]. Retrieved from: https://online.zakon.kz/document/?doc_id=31295286 (accessed 10 April 2021).

11. Ugolovnyj kodeks Respubliki Tadzhikistan: Zakon Respubliki Tadzhikistan ot 21.05.1998 g. № 574 (s izmeneniyami i dopolneniyami po sostoyaniyu na 17.12.2020 g.) [Criminal Code of the Republic of Tajikistan: Law of the Republic of Tajikistan dated May 21, 1998, No. 574 (with amendments and additions as of December 17, 2020)]. Retrieved from: http://continent-online.com/Document/?doc_ id $=30397325$ (accessed 10 April 2021).

12. Ugolovnyj kodeks Kyrgyzskoj Respubliki: Zakon Kyrgyzskoj Respubliki ot 02.02.2017 g. № 19 (s izmeneniyami i dopolneniyami po sostoyaniyu na 31.12.2020 g.) [The Criminal Code of the Kyrgyz Republic: Law of the Kyrgyz Republic dated 02.02.2017 No. 19 (with amendments and additions as of 31.12.2020)]. Retrieved from: http://cbd.minjust.gov.kg/act/view/ru-ru/111527 (accessed 10 April 2021).

13. Ugolovnyj kodeks Respubliki Armeniya: Zakon Respubliki Armeniya ot 18 April 2003 g. [The Criminal Code of the Republic of Armenia: Law of the Republic of Armenia dated April 18, 2003]. Retrieved from: http://www.parliament.am/ legislation.php?sel=show\&ID=1349\&lang=rus (accessed 10 April 2021). 